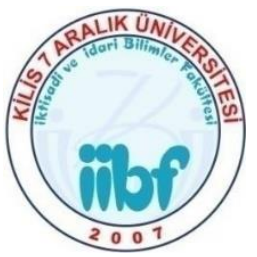

Journal of Academic Researches and Studies 2021, 13(25), 607-617

Akademik Araştırmalar ve Çalışmalar Dergisi 2021, 13(25), 607-617

https://doi.org/10.20990/kilisiibfakademik.980371

\title{
The Age of Popular Protests ${ }^{1}$
}

\section{Küresel Protestolar Çağ}

Mesut ŞÖHRET ${ }^{2}$

\begin{abstract}
Purpose: The purpose of this research is to examine the difference between the global protests, which have increased unexpectedly in the last decade, from the global protests in the past. In this way, it is to show the main points between the global protests and to reveal how the mass demonstrations taking place around the world have changed numerically and regionally.

Design/Methodology: In the research, qualitative and quantitative research methods were used and the global protests that took place around the world, especially the developments that took place in the last ten years, were supported by graphics and maps. This study is a research article and literature review technique was used.

Findings: While every mass protest over the past decade has its own context, these global mass protests are based on common grievances such as economic hardship, ineffective governance, political crisis, ethnic and religious discrimination, and corruption. The interesting thing is that while our world is witnessing new technological inventions and discoveries every day, this dissatisfaction is increasing. At this point, not only the number of countries where these mass demonstrations took place has increased significantly in the last ten years, but also the number of participants in these demonstrations is increasing day by day. In addition, mass demonstrations are increasing not only in underdeveloped countries but also in developed and developing countries.

Limitations: The study examines the developments of the global protests that occurred around the world in the 10-year period between 2009-2019. In addition, it tries to examine the similarities between the protests from a global perspective by aiming to explain the global protests that took place in general.
\end{abstract}

Originality/Value: The originality of the research is that it examines the development of global protests, especially taking into account the last ten years, and tries to explain the difference between these protests and global protests in the past. In addition, the study tries to support the arguments it defends with graphics and maps obtained from statistical data.

Keywords: Popular Protest, Popular Movements, Mass Demonstrations, Social Movements, COVID-19 Pandemic, AntiGovernment Protests
Öz

Amaç: $\mathrm{Bu}$ araştırmanın amacı, özellikle son on yılda dünya genelinde beklenmedik şekilde büyük bir artı̧̧ gösteren küresel protestoların geçmişte meydana gelen küresel protestolardan farkını incelemektir. Böylelikle küresel protestolar arasındaki temel noktaları göstermek ve dünya çapında gerçekleșen kitlesel gösterilerin sayısal ve bölgesel olarak nasıl değiştiğini ortaya koymaktır.

Tasarım/Yöntem: Araştırmada nitel ve nicel araştırma yöntemlerinden yararlanılmış ve dünya çapında meydana gelen küresel protestolar özellikle son on yılda meydana gelen gelişmeler grafik ve haritalarla desteklenmiştir. Bu çalışma araştırma makalesi niteliğinde olup literatür incelemesi tekniği kullanılmıştır.

Bulgular: Son on y1llık dönemde meydana gelen her kitlesel protestonun kendine özgü birbağlamı olmasına rağmen, bu küresel kitlesel protestolar ekonomik zorluklar, etkisiz yönetim, siyasi kriz, etnik ve dini ayrımcılık ve yolsuzluk gibi ortak şikâyetlere dayanmaktadır. Dünyamız her geçen gün yeni teknolojik icatlara ve keșiflere sahne olurken, bu memnuniyetsizlik giderek artıyor. Geldiğimiz noktada, son on yılda sadece bu kitlesel gösterilerin gerçekleștiği ülke sayısı önemli ölçüde artmakla kalmamıș, aynı zamanda bu gösterilere katılanların sayısı da her geçen gün artmaktadır. Ayrıca kitlesel gösteriler sadece az gelişmiş ülkelerde değil, gelişmiş ve gelişmekte olan ülkelerde de artmaktadır.

Sınırlılıklar: Calıșma genel olarak dünya genelinde meydana gelen küresel protestoların 2009-2019 arası 10 yıllık dönemdeki gelişmelerini incelemektedir. Bunun yanında meydana gelen küresel protestoları genel olarak açıklama amacı taşıyarak protestolar arasındaki benzerlikleri küresel bir bakış açısıyla incelemeye çalıșmaktadır

Özgünlük/Değer: Araştırmanın özgünlüğü küresel protestoların gelişimini özellikle son on yıllık dönemi dikkate alarak incelemesi ve bu protestoların geçmiş zamanlardaki küresel protestolardan farkını ortaya koyarak açıklamaya çalışmasıdır. Bunun yanında çalıșma istatiksel verilerden elde edilen grafik ve haritalarla savunduğu argümanları desteklemeye çalışmaktadır.

Anahtar Kelimeler: Popüler Protestolar, Popüler Hareketler, Popüler Gösteriler, Siyahların Hayatı Önemlidir, COVID-19 Salgını, Hükümet Karşııtı Protestolar

\footnotetext{
${ }^{1}$ This study is derived from the paper entitled "The Age of Popular Protests Around the World" presented by the author at The Euroasia Congress on Scientific Researches and Recent Trends-VII Congress held in Baku / Azerbaijan between 7-8 December 2020.

${ }^{2}$ Assist. Prof. Dr., Gaziantep University, Faculty of Economics and Administrative Sciences, Department of International Relations, sohretmesut@yahoo.com, ORCID: 0000-0003-4052-9286
} 


\section{INTRODUCTION}

Nowadays, the world is facing an age of global mass protests that are historically unexpected in frequency, scope, and size. Although each protest has a unique context, these global mass protests are based on common complaints such as economic difficulties, ineffective governance, political crisis, ethnic and religious discrimination and corruption. The interesting thing is that while our world is in the scene of new technological inventions and discoveries every day, such dissatisfaction is increasing. At the point we have reached, not only the number of countries where these mass demonstrations took place has increased significantly in the last decade, but also the number of people participating in these demonstrations is increasing day by day. In addition, mass demonstrations are increasing not only in less developed countries but also in developed and developing countries.

The popular mass protests demonstrating against economic crisis, fiscal austerity, political corruption and finally COVID-19 pandemic have brought down governments in democracies around the world from Africa, Asia, Latin America to North America, and Europe as well. Thanks to the advent of new communication technologies and social media platforms, what happens anywhere in the world can be seen everywhere now. The target audiences of popular protests are not only domestic politicians or their governments. The demands and requests of these unhappy people become known to the whole world in a short time. New communication technologies and social media platforms not only create awareness among people but also enable protesters in different countries to learn from each other about protest techniques and methods and to interact with each other. The messages and actions of these protesters have inspired and guided demonstrators in other parts of the world. This study aims to reveal an increase in popular protests and the main reasons behind the current popular movements starting from the last decade and the possible effects of these protests.

\section{CHANGING FEATURES OF POPULAR MOVEMENTS}

Citizens have at their disposal various instruments to express their discontent in the context of liberal democracies today: from voting in elections to directly contact public officials, from signing petitions to rejecting to buy certain products for political perceptions, from engaging in community action groups to participating in street demonstrations, and so forth (Giugni \& Grasso, 2019: 2). In this respect, it is possible to state that the industrial revolution and national revolutions caused a great transformation in the emergence of mass demonstrations in history. Social movements, in this perspective, were born out of this transformation and the street demonstration became part and along with the strike, the public rally, and the election.

This also stresses a key feature of this form of mobilization today: the street demonstration, along with the petition and the internet call-to-"action" (mass protests), have become today "modular performances," or "generic forms that can be adapted to a variety of local and social circumstances" (Tilly \& Tarrow, 2015: 17). In the past, although there have been demonstrations with some goals such as anti-tax riots, riots against conscription and livelihood riots, today demonstrations are used by different actors for different subjects and different purposes.

In this regard, Tilly and Tarrowdefine the social movement as "a sustained challenge to power holders in the name of a population living under the jurisdiction of those power holders by means of repeated public displays of that population's numbers, commitment, unity, and worthiness" (Tilly \& Tarrow, 2015: 11). They have also put much emphasis points out that the definition of an event as a social movement should include the following situations (Tilly \& Tarrow, 2015:11):

1) "Sustained campaigns of claim-making,

2) An array of public performances including marches, rallies, demonstrations creations of specialized associations, public meetings, public statements, petition letter writing and lobbying,

3) Repeated public displays of worthiness, unity numbers and commitments such means as wearing colours, marching in disciplined ranks, sporting badges that advertise the cause, displaying signs, chanting slogans and picketing public buildings they draw on,

4) The organization networks traditions solidarities that sustain these activities in social movement bases". 
However, their definition and the factors that they put forward to define an event as a social movement changed in the short term. Furthermore, the number of demonstrations, as well as the number of people taking part in them, has increased considerably in recent decades, with new postmaterialistic concerns developing alongside older socio-economic issues leading to a general increase in issues generating protest. This growing importance of peaceful protests was paralleled by an increased legitimacy accorded to such actions by both citizens and the state, which has led to a normalization of protest behaviour and demonstrations have become one of the major channels of public voice and participation in representative democracies (Aelst \& Walgrave, 2001: 480).

The normalization of protest, the most common and widespread form of participation beyond voting and beyond certain other forms, suggests that it is no longer confined to union militants, progressive intellectuals, and committed students so that "on the street we are all equal" (Aelst \& Walgrave, 2001: 480). The rise of "emotional mobilizations" is further seen to contribute to normalization. Having become so central in contemporary politics, street demonstrations are an appropriate object of study particularly if one wishes to examine who participates in protest activities, for what reason, and how they are mobilized. Demonstrations are the most typical form of contentious politics, they are used by different types of people to protest on a variety of issues, and they have become increasingly popular among different social strata (Aelst \& Walgrave, 2001: 480).

The "identification of a generic "other" creates bonds of solidarity and thus intensifies feelings of community. Setting the boundaries between a challenging group and its adversaries in terms of interest and/or values is a virtually universal pattern in collective identity formation. The identification of one another, whether as "the other" or as an enemy, creates bonds of solidarity and intensifies feelings of community" (Casquete, 2006: 45). Second, informal friendship points to a different way of developing "we" consciousness. In these social networks (consciousness-raising groups, various kinds of clubs, reading groups, newspapers, workshops, membership of social networks, use of social media tools such as Facebook, Twitter and etc.), "individuals interact face to face or virtually and find the chance to develop alternative cultural codes. Third, ceremonial and ritual behaviour, including mass gatherings, rallies, parades, grand shows and commemorations, also serves to build and convey a sense of 'we"' (Casquete, 2006: 45-46).

Protests can be excitement and even entertainment that goes beyond the boredom of daily life, due to all the physical and legal dangers it brings. When everyone shows solidarity, this attitude turns into fashion. Each wave mimics the others to some extent. But it is also a fact that the presence of smartphones has caused a radical transformation in the organization of the protests, their reaching and continuing. There is hardly a single indication that this wave will end soon. So this third wave of protest (following the late 60s and late $80 \mathrm{~s}$ ) may be a new de facto situation rather than the leading jolts of a global revolution.

\section{THE ANTI-GLOBALIZATION EFFECTS ON POPULAR MOVEMENT}

The phenomenon of globalization, which started to be voiced in the capitalist economic system in the world since the end of the 1980s, was not only the spread of the capitalist mode of production all over the world but also the indicator of the fact that the multinational companies found themselves in a privileged position within the system. "Since the beginning globalization, have caused much discussion. Supporters of globalization claim that it is inevitable and beneficial for everyone. However, another group is opposed to globalization, at least to its economic and political consequences. In this context, anti-globalization movements, emerging as the result of these changes, have become one of the most popular social movements" (Gümrükçü, 2010: 163). Anti-globalization movements firstly emerged in Western countries during the 1990s and gradually spread to other countries. Anti-globalization movements have also been widespread through the effect of relational and non-relational factors, such as direct ties among networks, media, and technology. Masses argue that the globalization process only benefits the elite and the wealthy while punishing ordinary workers and people in the lower and middle classes.

While the world is experiencing a globalization process, on the other hand, states are trying to strengthen their national borders with walls. Globalization envisioned a Kantian global liberal peace in which there would be no war and conflict in the world as a result of the unimpeded circulation of 
capital, the liberalization of trade, and the eventual disappearance of the national character of economies (Uzgel, 2018). However, in the last 30 years, it is quite surprising to see that a world model has emerged, which has transformed into a more closed world with more obstacles and increased conflicts instead of unhindered and free movement. At this point, seeing the emergence of global realist states instead of the closed states before 1990 creates a serious contradiction with the liberal global system ideal. In this respect, it can be said that the concept of the world without borders is already buried in history. In the 32 years since the fall of the Berlin Wall, about 80 countries have surrounded their borders with walls or fences, and this number seems to be increasing every year. However, this number did not exceed a dozen during the Cold War period, when the Berlin Wall was standing and there was ideological polarization (Wallet, 2016:2)

Although the global order did not completely kill the pursuit of nationhood and being a part of the nation, it did cause it to change form. Nation-states, defined by concepts such as 'over', 'collapsed', 'shrinked', 'the end has come' since the 1990s, were returning to the system with their redefined content, formatted to feed totalitarian systems. The ideology of globalization did not bring unity or freedom as it claimed, on the contrary, it caused negativities in a way that turned people's expectations and hopes upside down. The increase in human mobility, the closing of the distances between societies, and the fact that everyone became connected with everyone and everything brought serious confusion (Arıboğan, 2019: 43).

There are authors who express anti-globalization movements in different ways; "comprehensive globalization movements" anti-globalization movements attack neo-liberalism while calling for "holistic globalization" (Porta \& Kriesi, 1999). Similarly, that the participants in the movement not only oppose "multinational corporate power ... they also tend to reject the consumerism and the dominant ethos of modern capitalism" (Buttel, 2003: 101).

The post-globalization winds of social change were creating strange hybrids, removing the economic, political and moral differences that existed between phenomena and concepts in the Western world, such as liberalism and conservatism, left and right populism and authoritarianism. To survive and maintain interest, political parties surrendered to demagogue politicians and the extremely harmful populism of emerging trends. Political leaders did not hesitate to abandon their old world views on many issues and adopt the new realities and their advocates. The strongest vein that fed populism was the ideas of 'anti-globalization' and 'nationalism' (Arıboğan, 2019: 47).

Close examination of mass protests against globalization reveals the extent of the differences between various groups and their actions. Groups use civil disobedience, consumer activism, mass demonstrations and direct action, as tactics. These may include protest events held at "international and transnational summits, particularly economic organizations and social forums held both locally and globally, as well as anti-war protests, environmental protests, etc. The groups use direct action, civil disobedience, mass demonstrations, and consumer activism as tactics" (Porta, 2006: 6).

"These social movements use new kinds of protest forms, such as organizing in transnational networks and electronic activism" (Smith, 2001: 11). The action repertoires of these movements include nationally, and even regionally, specific aspects. "There are also different participating groups such as anti-racist, feminist, environmentalist, gay and lesbian, student, and peasant groups, labour unions, and political parties" (Ayres, 2004: 11-34). "All these protest events and organizations with different actors, action repertoires, and organizational structures demonstrate that "anti-globalization movements" actually refer to a "heterogeneous" structure with a common target: capitalism" (Gümrükçü, 2010: 164).

Anti-globalization movements first attracted the attention of the world with the demonstrations against the World Trade Organization's Third Ministerial Summit held in Seattle in 1999, and then all anti-capitalist actions have come to the present day, especially with the actions of left organizations and anarchist groups.

On the other hand, as a result of the increase in globalization in the last decade, it has become undeniable that it causes many problems even in the developed countries that benefit most from this development and increases the problems in the less developed regions of the world. For this reason, not only anarchist groups and leftist groups but also ordinary people and people on the right in some 
countries participate in the demonstrations. "All this has led to the strengthening of resistance and protest within society, both in the 'North' or 'West' and in the 'South' or-to a lesser extent-in the 'East'. This resistance appears in the form of the so-called 'anti-globalization' or globalizationcritical' movements" (Artner, 2004: 243-255).

\section{GROWTH OF GLOBAL POPULAR PROTESTS}

The size and frequency of mass demonstrations that have taken place in the world over the last 10 years overshadow the historical examples of periods of mass protest such as the late 1960s, (the rise of left movements) late 1980s (collapse of socialist bloc) and early 1990s (Anti-globalization movements). On the other hand, analysis of Global Protest Tracker reveals that mass demonstration from 2009 through the present and found that the number of anti-government protests increased around the world by an annual average of $11.5 \%$ between 2009 and 2019 though there was significant variation within regions and year to year (Brannen et al., 2020: 1).

Although there is a global decrease in popular protests due to health conditions during the COVID-19 pandemic process, early 2020, "as the deadly coronavirus spread rapidly around the world and governments instituted social distancing requirements and bans on public gatherings to limit the contagion, the mass street demonstrations that had characterized the protest wave largely came to an end" (Pinckney \& Rivers, 2020). But it is expected to increase due to both the discontent caused by the global epidemic and the discomfort from the economic and political system. Analysis of the root causes of these global protests shows that they will continue and may increase in 2020 and beyond.

The common feature of the protests taking place is that they are anti-government and antisystem. In this context, while anti-government demonstrations were held in 114 countries in 2019 alone, this number corresponded to an increase of 31 percent compared to 10 years ago. After many demonstrations held in 2019, heads of state and government had to resign in countries such as Lebanon, Iraq, Bolivia, Algeria, Sudan, and Malta and Peru. Moreover, in many countries, the police forces were insufficient and the military forces had to intervene in the mass demonstrations. In addition to such development, the number of participants was also remarkable in the popular protests in 2019. For example, On June 16, 2019, Approximately 2 million people participated in the demonstrations in Hong Kong, which has a population of approximately 7.4 million (Hong Kong Protest, 2019.) In addition, on October 25, 2019, the number of demonstrators in Santiago, the capital of Chile with a population of 5.1 million, reached 1 million (Sherwood \& Miranda, 2019). Another interesting common point of the anti-government demonstrations is that similar demonstrations are being held in countries with advanced economies and they are growing at a faster rate in Europe and North America than the global average. In the advanced economies like Western Europe and North America the economic crisis and anti-austerity protests encouraged by government measures to combat it have also sparked new complaints. Moreover, they resurrected old complaints and problems that were somewhat marginalized by new lifestyle-oriented social movements. Especially in countries where the pacification of traditional class division provides a wider scope for such issues to become the basis for political mobilization. These relate to problems of inequality and resource allocation in developed industrial societies (Giugni \& Grasso, 2019: 2).

In fact, the world's almost next to each occurring before the global popular protest era of the former US National Security Advisor Zbigniew Brzezinski in 2008 the peak of the global financial crisis and the Arab Spring, a kind of "global political awakening" as defined. Expressing that a new era of global activism has begun in this new era, he gave the clues of this new era by saying "For the first time in history, almost all of humanity is politically active, politically conscious and politically interactive" (Brzezinski, 2008). In line with Brzezinski's definition, governments and leaders around the world today are being tested by increasing citizen expectations, fueled by high rates of change. Protesters are increasingly targeting public and private infrastructure and businesses with chain social and economic impacts.

The economic consequences of mass protests and their potential impact on countries are enormous. Because civil unrest is triggering billions of dollars in damage to businesses, national economies and investments worldwide. In fact, although these protests seem to have emerged out of 
nowhere, the structural problems that the states have not been able to solve for a long time and the resulting disappointment in ordinary civilians constitute the main source of these protests.

\section{THE RISE OF POPULAR PROTESTS BY THE REGION}

Just after the Global Financial Crisis in 2008, anti-globalization and consequently anticapitalist demonstrations have increased in developed or underdeveloped countries. In fact, it should be noted that although the demonstrators in many countries did not directly start a protest against globalization and the capitalist system, these two phenomena were behind the majority of demonstrations. As seen in the map below, it is possible to say that there is a serious increase in mass demonstrations made both numerically and proportionally in all regions of the world.

Figure 1: Map of Regional Mass Demonstrations by the Region

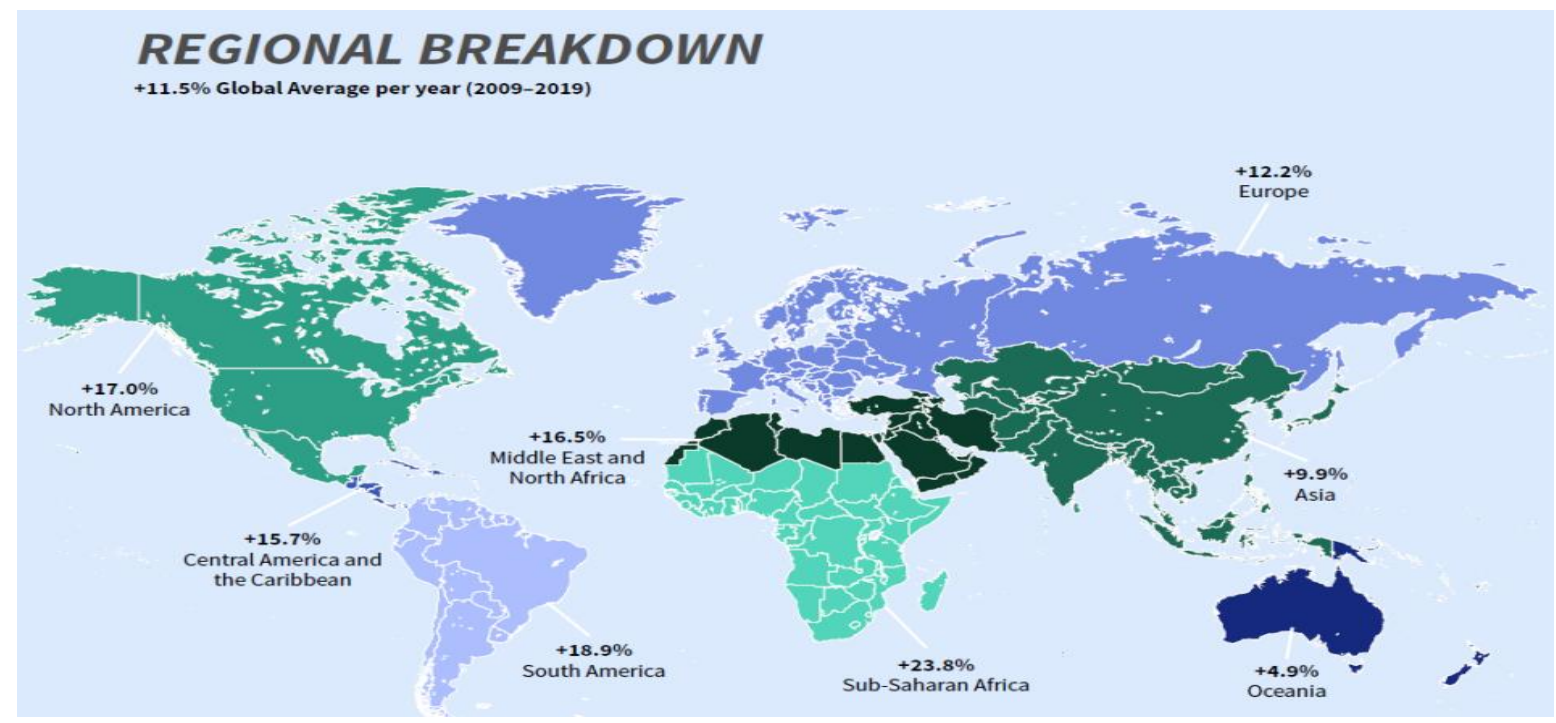

Source: Brannen et al., 2020: 4

According to the map above, the largest proportional increase between 2009 and 2019 is seen in the Sub Saharan Africa region with an increase of approximately $24 \%$. The fact that the most seen increase is in this region is undoubtedly due to the fact that most of the states called failed states are here. It seems understandable that mass demonstrations are made in these places, as these states are inadequate to provide the necessary services to their citizens and are often suffering from civil war or famine.

The second-largest proportional increase between 2009 and 2019 is seen in the South America region with an increase of approximately $19 \%$. The fact that the most seen increase is in this region is mainly based on economic and political conditions and also corruption claims. The economic crisis has made painfully evident the vulnerabilities of the South American economies. The volatile behaviour of commodity prices has had hard times for economies that rely heavily on international markets for exports as well as food imports. The worsening market conditions revealed deeper rightto-left structural problems and shortcomings in Latin American modernization strategies (Rénique, 2009: 5).

Surprisingly, the third-largest proportional increase between 2009 and 2019 in the North America region with an increase of approximately $17 \%$. It is quite surprising to see such an increase in a region with two developed economies and democratic states, such as the USA and Canada. Of course, it is seen that the rise of mass demonstrations in this region, especially due to the economic and political developments in the USA, as well as the uprisings that emerged due to racial discrimination in the social field, had a great effect. For example, "Black Lives Matter (BLM), an international social movement, formed in the United States in 2013, dedicated to fighting racism and anti-Black violence, especially in the form of police brutality. The name Black Lives Matter signals condemnation of the unjust killings of Black people by police (Black people are far more likely to be killed by police in the United States than white people) and the demand that society value the lives and 
humanity of Black people as much as it values the lives and humanity of white people. In 2020 George Floyd, an unarmed Black man was pronounced dead after a white Minneapolis police officer knelt on Floyd's neck for several minutes, despite Floyd's repeated protests that he could not breathe. Wide circulation of a bystander's video of Floyd's last minutes triggered massive demonstrations in cities throughout the United States and across the globe. The tragedy swayed U.S. public opinion in favour of the Black Lives Matter movement while drawing wide attention to the problem of entrenched racism in American society" (Black Lives Matter, 2020).

On the other hand, the fourth largest proportional increase in the same period is seen in the Middle East and North Africa region with an increase of $16.5 \%$. It is possible to say that the mass demonstrations in this region, especially in the period called the Arab Spring, which started in 2011, played an important role in this increase. Even though a period of about 10 years has passed, demonstrations against the governments and the current order still continue in this region. For example; In Lebanon, the Government's imposition of 6 dollars a month tax on citizens as WhatsApp tax caused great anger across the country, causing people to start large-scale protests. After the people's reaction, the government had to cancel the tax within a few hours. In fact, the reaction of the people was an indication of the discontent of the people, whose living standards have fallen due to mismanagement for many years. "On October 29, 11 days after the protests began, Prime Minister Saad Hariri resigned. However the protests continued because people are fed up with government corruption and incompetence" (Wanlund, 2020, pp.12).To put it bluntly, economic data justifies the demonstrators. Because "Lebanon is dealing with its worst economic crisis in decades. It has the thirdhighest public debt-to-gross domestic product (GDP) ratio in the world at $150 \%$. The youth unemployment rate has reached $37 \%$, according to official figures, while the overall unemployment rate is $25 \%$. Almost a third of the population now lives under the poverty line, according to the World Bank" (Lebanon Protests, 2019).

Another interesting development is seen in the European region. The living standards and socio-economic development level are quite high in general, the increase of about $12 \%$ of the mass demonstrations in the last 10 years. Although the living standards of the people living in this region are relatively better than other regions, it is seen that the rate of discontent in people is gradually increasing. This shows that this region is now a difficult region for governments. For instance, "France's gilets jaunes (yellow vests) protests, named for the high-visibility safety jackets that French motorists must carry, were triggered by a proposed increase in the national fuel tax in 2018 . The tax was abandoned in April 2019. The size of the protests dwindled, but they continued as part of a wider anti-government movement" (McAuley, 2019). While mass protests took place in at least 37 countries, these movements increased globally in 25 percent of countries throughout 2019 and concentrated towards the end of the year in Hong Kong, Chile, Nigeria, Sudan, Haiti and Lebanon.

Graphic 1: Number of Anti-Civilian Government Protests by Region Quarterly

QUARTERLY CIVILIAN ANTI-GOVERNMENT PROTESTS BY REGION (\#)

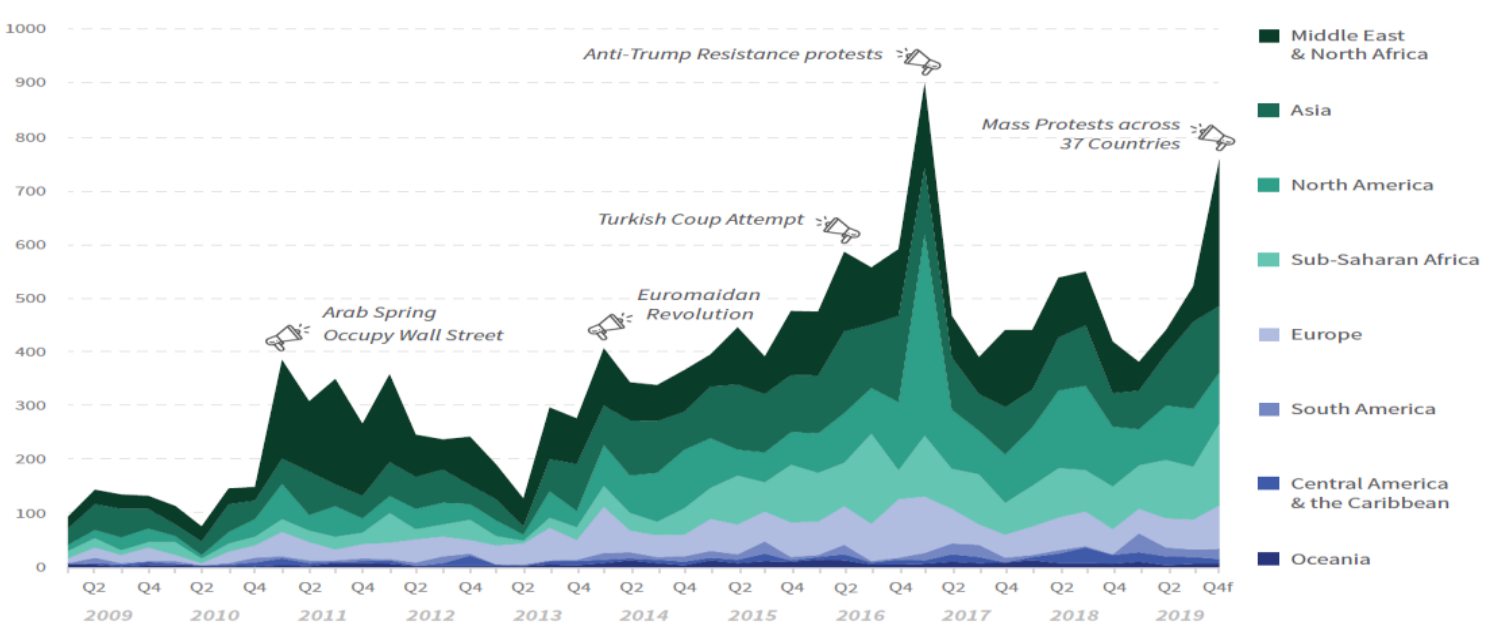

Source: Brannen et al., 2020: 5 
On the other hand, when the quarterly distribution of mass demonstrations is analyzed, it is seen that there is a trend that started in the second quarter of 2010. Undoubtedly, Occupy Wall Street and Arab Spring are seen as the reason for this increase. However, it is seen that mass demonstrations dropped dramatically in the second quarter of 2013, but showed a rapid increase trend after this quarter and reached a peak in the 4th quarter of 2016. In this period, when mass demonstrations reached their peak, it is observed that the striking developments stemmed from the demonstrations especially in Europe and the USA. Accordingly, the Euromaidan demonstrations that started in Ukraine turned into an ongoing struggle for ideological and geopolitical hegemony between Russia and the West, (Diuk, 2014: 10) causing the instability of Ukraine. On July 15, 2016, after the failed coup attempt occurred in Turkey continued for months has been in all cities of Turkey's democracy seizures led to a high concentration in mass demonstrations. Mass demonstrations against Donald Trump, who was surprisingly elected president after the elections held in November 2016 in the USA, increased rapidly after the election results were announced and caused intense protests in many states of the USA. Even after Trump was elected president, his visits to many allied countries caused mass demonstrations in these countries. For example, Trump was protested by nearly 400,000 people during his official visit to the UK in June 2019 (Roache, 2019).

As it is clearly seen in the chart above, although the global anti-government protests are in a fluctuating trend in the regional sense, it is seen that in general, it has increased by an average of $11.5 \%$ in the last 10 years.

On the other hand, according to Global Protest Tracker data, there are important trends in the most important anti-government protests around the world between 2017 and December 2, 2020. So much so those about 100 significant anti-government protests have erupted worldwide during this period. Also after the mass protests about 30 governments or leaders have fallen as a result. However, in this period, it is observed that mass demonstrations were concentrated especially in the South American region. In this process, in 8 out of 12 South American countries, it is seen that these demonstrations escalated seriously in countries such as Chile, Peru and Nicaragua despite the global pandemic (Global Protest Tracker, 2020).

In 2020, the worsening economic conditions due to COVID-19 and the inaction of governments to address the problems facing people, as well as the lockdowns due to the epidemic, led to large-scale mass protests in many countries. Millions of people around the world have taken to the streets to demand jobs, democratic freedoms, social justice and an end to corruption.

Figure 2: Map of Number of Protest between 2010-2020

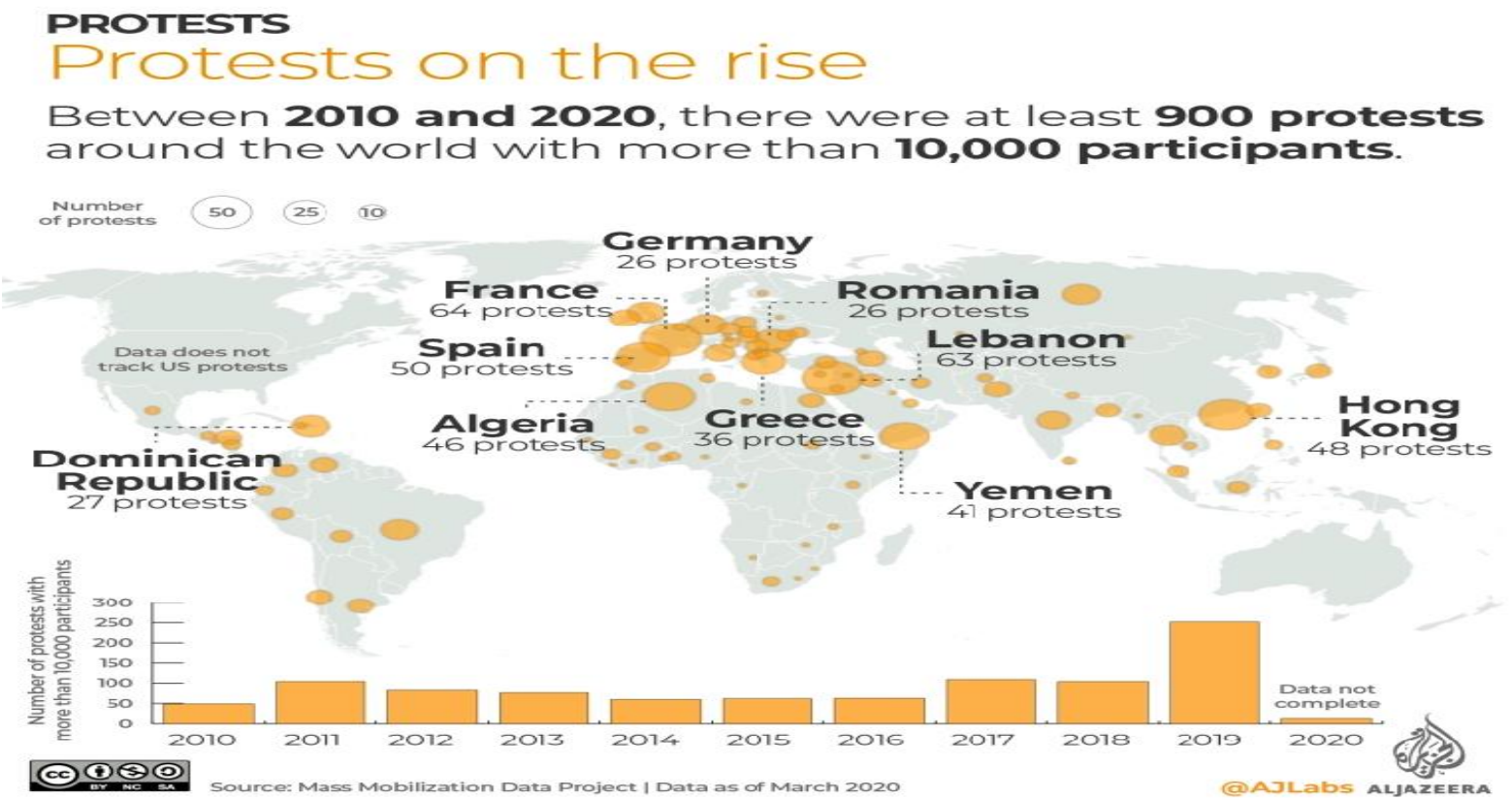

Source: Haddad, 2020 
"The mass mobilisation data project, which tracks protests outside the United States, has recorded nearly 7,000 protests from 153 countries over the past 10 years. While most protests range from hundreds to thousands of demonstrators, between 2010 and 2020, there were at least 900 protests around the world with more than 10,000 participants" (Haddad, 2020). As can be seen in Figure 2 above, protests with large participation occur in underdeveloped countries such as Yemen, Lebanon, Algeria and the Dominican Republic, as well as in developed countries that are members of the European Union such as Germany, France, Spain, Romania and Greece. There was also a significant increase in these protests in 2019. This situation undoubtedly gives us the following message. There is serious discontent among ordinary people in almost every country in the world, whether developed or underdeveloped, democratically governed, authoritarian or dictatorial.

\section{CONCLUSION}

The world has entered a new 10-year period of rage and unrest. Politicians and governments of countries should analyze the reasons behind the mass protests and develop new discourses and policies. Otherwise, the effects and intensity of the protests will continue to increase in the coming years. At the beginning of 2020, the level of unrest in the world reached its highest level in history. However, in the first months of 2020, it continued to boil in the background, with the economic and political developments experienced in the first months of the COVID-19 outbreak and related lockdowns.

The anger that has turned into street protests over the past 10 years has surprised many governments. Governments have often responded to such cuts by making limited concessions and blocking by security forces, ignoring the root causes of the problem. Even if governments are determined to manage the problems that anger the protesters, the solutions to the complex challenges that precipitate the unrest are not simple problems that can be solved overnight. It is not easy to find a magical solution to the mismanagement, economic and political problems seen in many countries. It seems that in the near future, multinational cooperations and investors will have to adapt to this process, seeing mass protests as the "new normal" for the foreseeable future.

It is difficult to predict when and how a mass protest will start. "Looking more broadly at geopolitical, regional, and internal issues and seeing the connections between them helps build the bigger picture over time. No single source of information can predict a mass protest. However, various economic and social indicators can provide insight into how the situation is likely to develop" (Center \& Arendt, 2020). In addition to economic difficulties and the decline in people's living standards, significant fluctuations within countries are often the most important driving forces of mass protests. The reasons such as price increases in basic products in the country, stagnation of salaries and declining purchasing power of people cause great difficulties and discontent in the general population. According to the forecasts of global monetary institutions such as the IMF, WB and WTO it predicted a global economic slowdown in 2020. Normally, such a slowdown does not trigger large-scale social and international political international crises, but with other factors caused by the COVID-19 pandemic, it seems highly likely that mass protests will increase in the coming years.

"Political systems in many of those countries have failed to deliver a more fair distribution of wealth and participatory framework to political decision-making. That is why the fundamental divide in politics will be between pro- and anti-establishment political forces rather than between ideological, ethnic or religious divisions. It is still not clear whether the anti-system or anti-establishment parties will attract street activism to the electoral domain, but it seems that the conventional political arrangements will face a structural transformation in the coming years. The world is heading toward an era of uncertainty. The conventional political and social tools and processes will be futile in maintaining societal peace and stability in this new era. The structural roots of economic inequalities and unfair income distribution should be addressed and more participatory and more inclusive political frameworks must incorporate disenchanted groups, especially the unemployed youth" (Köse, 2020). 
Ethics Statement: In this study, no method requiring the permission of the "Ethics Committee" was used.

Etik Beyan: Bu çalışmada "Etik Kurul” izni alınmasını gerektiren bir yöntem kullanılmamıştır.

\section{REFERENCES}

Aelst, V., \& Walgrave, S. (2001). Who is that (wo)man in the street? From the normalisation of protest to the normalisation of the protester. European Journal of Political Research, 39(4), 461-486. https://doi.org/10.1111/1475-6765.00582

Arıboğan, D. Ü. (2019). Duvar: Tarih geri dönüyor. İnkılap Kitapevi.

Artner, A. (2004). Anti-globalization movements: The developments in Asia. Contemporary Politics, 10(3-4), 243-255. https://doi.org/10.1080/1356977042000316709

Auley, J. Mc. (2019, November, 16). 'Yellow vest' anniversary: What happened to the movement that shook France?. The Washington Post. https://tinyurl.com/u8599be

Ayres, J. M. (2004). Framing collective action against neoliberalism: The case of the 'anti globalization' movement. Journal of World-Systems Research, 10(1), 11-34. https://doi.org/10.5195/jwsr.2004.311

Black lives matter. (2020, August, 13). Encyclopedia Britannica. https://www.britannica.com/topic/Black-Lives-Matter

Brannen, S. J., \& Haig, C. S., \& Schmidt, K. (2020). The age of mass protests: Understanding an escalating global trend. The Center for Strategic and International Studies Report, Washington, D.C. https://csis-website-prod.s3.amazonaws.com/s3fspublic/publication/200303 MassProtests V2.pdf?uL3KRAKjoHfmenFENNWTXdUbf0Fk0Qk $\underline{\mathrm{e}}$

Brzezinski, Z. (2008, December 16). The global political awakening. The New York Times. https://www.nytimes.com/2008/12/16/opinion/16iht-YEbrzezinski.1.18730411.html

Buttel, F. H. (2003). Some observations on the anti-globalisation movements. Australian Journal of Social Issues, 38(1), 95-116. https://doi.org/10.1002/j.1839-4655.2003.tb01138.x

Casquete, J. (2006). The power of demonstrations. Social Movement Studies, 5(1), 45-60. https://doi.org/10.1080/14742830600621183

Center, M., \& Arendt, D. (2020, September 1). Corporate resilience: How to anticipate mass protest and disruption. https://www.asisonline.org/security-managementmagazine/articles/2020/09/corporate-resilience-how-to-anticipate-mass-protest-and-disruption/

Diuk, N. (2014). Euromaidan: Ukraine's self-organizing revolution. World Affairs, 176(6), 9-16. https://www.jstor.org/stable/43555086

Giugni , M., \& Grasso, M. T. (2019). Protest politics and social movement activism in the age of globalization, In M. Giugni, \& M. T. Grasso (Eds.), Street citizens. Cambridge University Press, 1-26, https://doi.org/10.1017/9781108693455.002

Global Protest Tracker. (2020). https://carnegieendowment.org/publications/interactive/protest-tracker

Gümrükçü, S. B. (2010). The rise of a social movement: The emergence of anti-globalization movements in Turkey. Turkish Studies, 11(2), 163-180. https://doi.org/10.1080/14683849.2010.483849

Haddad, M. (2021). Mapping major protests around the world. Aljazeera. https://www.aljazeera.com/news/2021/3/30/mapping-major-protests-around-the-world

Hong Kong protest: 'Nearly two million' join demonstration. (2019, June, 17). BBC. https://www.bbc.com/news/world-asia-china-48656471 
Köse, T. (2019, November, 18). The age of mass protests and the new logic of politics. Daily Sabah. https://www.dailysabah.com/columns/talhakose/2019/11/28/the-age-of-mass-protests-and-thenew-logic-of-politics

Lebanon protests. (2019). How whatsapp tax anger revealed a much deeper crisis. (7, November, 2019). BBC. https://www.bbc.com/news/world-middle-east-50293636

Pinckney, J., \& Rivers, M. (2020, March 25). Nonviolent action in the time of coronavirus. U.S. Institute of Peace, https://tinyurl.com/y93qxzdo

Porta, D. D. (2006). The global justice movement: An introduction. In D. Della Porta (Ed.), The global justice movement: Cross-national and transnational perspectives. Paradigm.

Porta, D. D., \& Kriesi, H. (1999). Social movements in a globalising world: An introduction. In D. Della Porta, H. Kriesi, \& D. Rucht (Eds.), Social movements in a globalising world (pp. 3-22). Macmillan.

Rénique, G. (2009). Latin America: The new neoliberalism and popular mobilization. Socialism and Democracy, 23(3), 1-26, https://doi.org/10.1080/08854300903290801

Roache, M. (2019, June, 4). While thousands march, President Trump dismisses London protests as 'fake news'. Time. https://time.com/5600472/protest-trump-state-visit-uk/

Sherwood, D., \& Miranda, N. A. R. (2019, October, 25). One million Chileans march in Santiago, city grinds to halt. Reuters. https://www.reuters.com/article/us-chile-protests-idUSKBN1X4225

Smith, J. (2001). Globalizing resistance: The battle of seattle and the future of social movements. Mobilization: $\quad$ An International Quarterly, 6(1), 1-19. https://doi.org/10.17813/maiq.6.1.y63133434t8vq608

Tilly, C., \& Tarrow, S. (2015). Contentious politics. Oxford University Press.

Uzgel, İ. (2018, October, 1). Küreselleşme karşıtı Trump ve 'ilkeli realizm'. Gazete Duvar. https://www.gazeteduvar.com.tr/yazarlar/2018/10/01/trump-ve-kuresellesme-karsiti-olarakilkeli-realizm-kavrami

Wallet, E. (2016). Borders, fences and walls: State of insecurity?. Routhledge.

Wanlund, B. (2020). Global protest movements: Can they lead to lasting change?, CQ Researcher, 30(17), 1-30. https://library.cqpress.com/cqresearcher/document.php?id=cqresrre2020050100 